\title{
Researches Regarding the Eutypa Lata Lignicole Fungus Manifestation in Vineyards from Blaj Wine Centre
}

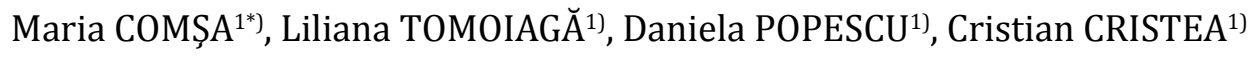 \\ ${ }^{1)}$ Reasearch Station for Viticulture and Enology Blaj, Romania \\ ${ }^{*}$ Corresponding author, e-mail: comsa_m@yahoo.com
}

Bulletin UASVM Horticulture 71(2) / 2014

Print ISSN 1843-5254, Electronic ISSN 1843-5394

DOI:10.15835/buasvmcn-hort:10674

\begin{abstract}
The responses of vine to the eutipoze attack were analyzed, depending on the age of the plantation. Of the four varieties studied, regardless of the plantation age, the lowest degree of attack was registered at 'Fetească regală' $(7.0 \%)$ and 'Sauvignon blanc' $(7.3 \%)$, the differences between being insignificant. The results confirm the data from the literature according to which the eutipoza is more widespread in plantations for over 10 years.
\end{abstract}

Keywords: Eutypa Lata, lignicole pathogen, vines.

Introduction. Eutypa lata attack a number of over 80 plant species belonging to 27 botanical families in temperate and Mediterranean area. The most common hosts are apricot, peach, plum, apple, vine, currant, gooseberry, etc. (Tomoiagă et al., 2007). It is a well known species in terms of spreading and virulence of the attack (Stoica and Ulea, 2004) and plays an important role in biological decline at vine. The eutipoza symptoms appear at a distance of 3-8 years after infection of the vine(Comşa, 2014).

Aims and objectives. The research aims to assess the response of vine to the eutipoze attack, depending on the age of the plantation (young plantation - 6 years and old plantation -over 25 years).

Materials and methods. The experiments were conducted in vineyards of SCDVV Blaj on varieties 'Fetească regală', 'Fetească albă', 'Sauvignon blanc' and 'Muscat Ottonel'. For assessing the way of the vine block reaction to eutipoza were placed two experimental plots (with the same varieties), in the vine plantations with different ages. On vines were conducted observations and measurements of the frequency and intensity of eutipoze attacks. For this purpose in 2012, were included in the study both the young vineyards in the age of 6 years and vineyards over 25 years.

\section{Results and Discussion.}

The two factors taken in the study (age of plantation and the variety) as well as their interaction have a very significant influence on the attack caused by Eutypa lata (Tab. 1). The greatest influence was exercised by the age of plantation $\left(\mathrm{F}_{\text {calc }}=1751.61>\mathrm{F}_{\text {teor }}=8.86\right)$, this influence being very significant.

Tab. 1. Analysis of variance for the attack degree (\%) of Eutypa lata pathogen in bifactorial experience type A x B (SCDVV Blaj, 2012)

\begin{tabular}{|c|c|c|c|c|c|}
\hline \multirow[b]{2}{*}{ Source of variation } & \multirow[b]{2}{*}{ SS } & \multirow[b]{2}{*}{ DF } & \multirow[b]{2}{*}{$\mathrm{s}^{2}$} & \multicolumn{2}{|c|}{ F Test } \\
\hline & & & & Vers & $\mathrm{LS} \mathrm{S}_{A \times B}^{2}$ \\
\hline Total & 1987.1 & 23 & & & \\
\hline Replications & 0.5 & 2 & & & \\
\hline A (Variety) & 249.2 & 3 & 83.1 & 95.70 & $>3.34 ; 5.56$ \\
\hline B (The plantation age) & 1520.0 & 1 & 1520.0 & 1751.61 & $>4.60 ; 8.86$ \\
\hline$A \times B$ & 205.2 & 3 & 68.4 & 78.83 & $>3.34 ; 5.56$ \\
\hline Error & 12.1 & 14 & 0.868 & & \\
\hline
\end{tabular}


Tab. 2. The effects of experimental factors and their interaction in Variety x Age of plantation experience, regarding the attack degree (\%) of Eutypa lata pathogen, at SCDVV Blaj in 2012

\begin{tabular}{lccc}
\hline Variety & 6 years & over 25 years & Average per variety \\
\hline Fetească regală & $1.0 \mathrm{a}$ & $12.9 \mathrm{~b}$ & $7.0 \mathrm{~A}$ \\
\hline Fetească albă & $1.4 \mathrm{a}$ & $16.0 \mathrm{c}$ & $8.7 \mathrm{~B}$ \\
\hline Muscat Ottonel & $2.0 \mathrm{a}$ & $27.9 \mathrm{~d}$ & $15.0 \mathrm{C}$ \\
\hline Sauvignon blanc & $1.6 \mathrm{a}$ & $13.0 \mathrm{~b}$ & $7.3 \mathrm{~A}$ \\
\hline Average per age of plantation & $1.5 \mathrm{M}$ & $17.4 \mathrm{~N}$ & \\
\hline
\end{tabular}

DS $5 \%$ for two age plantation means $=0.8 \%$

DS $5 \%$ for two variants means $=1.2 \%$

DS $5 \%$ for two variants $\mathrm{x}$ age plantation means $=1.6-1.8 \%$

Note: Difference between two values followed by at least one common point is insignificant.

Analyzing the attack degree, regardless of the varieties included in the study (Tab. 2), this has registered in young plantation a much lower value $(1.5 \%)$ compared whit that recorded in older plantations $(18 \%)$.

of the four varieties studied, regardless of the plantation age, the lowest degree of attack was registered at 'Fetească regală' $(7.0 \%)$ and 'Sauvignon blanc' (7.3\%), the differences between being insignificant. At a significant distance from them stood the 'Fetească albă' for this variety the attack degree caused by the pathogen Eutypa lata being $8.7 \%$.

The highest value of the attack degree was recorded at 'Muscat Ottonel', of 15\%, this variety, under condition of Blaj wine center, showing an adequate sensitivity quite high to the destructive action of this lignicol pathogen.

Between the eight experimental versions resulting from the factors interaction (age of plantation $\mathrm{x}$ variety), the all four varieties from young plantation stand out with low values (below $2 \%$ ) of the attack degree of pathogen Eutypa lata, this values being equal from statistic point of view.

At significant difference of these older plantations is classified: 'Fetească regală' $(12.9 \%$ GA) and 'Sauvignon blanc' (13.0\%). In contrast, the highest value of the attack was recorded in old plantation, at 'Muscat Ottonel', this variety having a value of $27.9 \% \mathrm{GA}$.

Conclusion. The results confirm the data from the literature according to which the eutipoza is more widespread in plantations for over 10 years (Tomoiagă et al., 2007, Oprea and Dumitru, 1988, Duthie et al., 1991). This does not necessarily mean that young plantations are less susceptible to attack of Eutypa lata, the absence of symptoms is due to the slow evolution of the pathogen in grapevine wood.

\section{REFERENCES}

1. Comşa M (2014). phD thesis, The study of biological decline of vine caused by lignicole pathogens, in Blaj Wine center. The USAMV, Cluj Napoca.

2. Duthie JA, Munkvold GPM, Marois JJ (1991). Relationship between age of vineyard and incidence of Eutypa dieback. Phytopatology 81:1183 - 1184.

3. Oprea M, Dumitru C (1988). Research on Pathogenic fungi involved in premature destruction of the vine. I.C.P.P. Annals Vol. XXII: 11-2.

4. Stoica MC, Ulea E (2004). The causes of premature destruction of vines in vineyards from Moldova, The ICDVV Valea Calugareasca Annals, Vol. XVII: 213-219

5. Tomoiagă L, Oprea M, Podosu A, Voiculescu I, Florian V, Stoica C, Iederan C (2007). Guide to identifying and combating vine decline, Ed. Prahova, Ploiești. 